\title{
Validation of reference genes for gene expression studies in bovine oocytes and cumulus cells derived from in vitro maturation
}

\author{
Lisandra Cristina Caetano, Cristiana Libardi Miranda-Furtado, Luciene Aparecida Batista, \\ Caroline Palmieri Pitangui-Molina, Thaís Tiemi Higa, Cristiana Carolina Padovan, \\ Ana Carolina Japur de Sá Rosa-e-Silva ${ }^{\S}$
}

\author{
Department of Gynecology and Obstetrics, Ribeirão Preto Medical School, University of São Paulo, Ribeirão Preto, SP, Brazil.
}

\begin{abstract}
Quantitative real-time PCR (qPCR) is a valuable tool for gene expression studies and it is necessary to choose an ideal endogenous reference gene for data normalization. This work studied a set of reference genes in oocytes and cumulus cells of COCs (Cumulus-Oocyte Complexes) that are suitable for relative gene expression analyses after in vitro maturation (IVM) in bovine. Immature COCs were collected from ovaries of Nelore cattle (Bos indicus) and submitted to IVM. MII oocytes and cumulus cells were subjected to RNA extraction, reverse transcription and preamplification of cDNA. The expression level of eight reference genes ( $A C T B, G A D P H, B 2 M, H 2 A F Z, G U S B$, HPRT1, PPIA, and TBP) was measured by real time PCR and analyzed by geNorm software. The gene stability measure (M) was calculated and the ideal number of reference genes (RGs) was determined by the $\mathrm{V}$ value (pairwise variation). For oocyte samples, two RGs were the ideal number for relative quantification: HPRT1 and $B 2 M$ and for bovine cumulus samples four were indicated: HPRT1, PPIA, B2M, and TBP genes. The normalization of a non-reference target gene (SOD1) by these reference genes was shown to be considerably different from normalization by less stable reference genes. Our results strengthen the importance of choosing good normalizing genes in order to analyze gene expression under specific experimental conditions and we suggest the use of these RGs in oocytes and cumulus cells of bovine cattle in in vitro matured COCs.
\end{abstract}

Keywords: cumulus cell, oocyte, reference genes.

\section{Introduction}

Bovine cattle have a biological and economic importance in which reproductive traits are a relevant component of livestock and genetic breeding (Cammack et al., 2009). Bovine ovary physiology and some aspects of embryo growth and development are very similar to humans, which makes this species a possible translational model for developmental studies and improvement of assisted reproduction technologies (ARTs) in humans (Ross et al., 2009).

During follicular development, many mRNAs and proteins are synthetized, which regulate oocyte growth and maintain early embryonic development until the embryonic genome is activated (Gosden 2002; Sutton et al., 2003). In this period, the bi-directional interaction between oocyte cumulus and granulosa cells, also called crosstalk, is essential to complete oocyte development (Senbon et al., 2003). Granulosa cells intercommunication, as well as their interaction with the oocyte, occurs through gap junctions, where many substances like glucose, proteins, and mRNA pass through (Bruzzone et al., 1996; Sugiura et al., 2005; Gilchrist et al., 2008). As a result of this crosstalk, cumulus cells may reveal information about oocyte health through gene expression and many studies investigate these substances as noninvasive molecular markers for good quality oocyte selection (Sugiura et al., 2005; Gilchrist et al., 2008; Hamel et al., 2008).

The level of gene expression is frequently evaluated by reverse transcription (RT) associated with the quantitative polymerase chain reaction (qPCR). Values obtained are calculated using comparative analysis with respect to reference genes (RG), also known as normalizing genes or endogenous controls, which allow the removal of typical technical and biological variations (Livak and Schmittgen, 2001). Optimal RGs should be sufficiently abundant across different tissues and cell types, and have consistent RNA transcription under different experimental conditions. However, there is no universal reference gene for all cell types and experiments since gene expression is tissue, space, and time specific (Radonic et al., 2004). Thus, it is necessary to choose specific candidate genes for each experiment among three or more reference genes (Hruz et al., 2011). Specific algorithms were created to evaluate expression stability among different genes and define an optimal reference gene (or genes) for specific cell lines in RT-qPCR experiments. geNorm, NormFinder, and BestKeeper are some algorithms often used as analysis programs to validate RGs (Vandesompele et al., 2002; Pfaffl et al., 2004; Andersen et al., 2004).

Considering the importance of gene expression analysis for developmental studies and the use of bovine as a model to study aspects of assisted reproduction, we verified the absence of validation of reference genes in bovine samples submitted to in vitro maturation. Therefore, the aim this study was to evaluate the stability of eight candidates for reference gene in in vitro matured oocytes and cumulus cells from Nelore cattle (Bos indicus), analyzed by RT-qPCR. 


\section{Methods}

\section{Ethics statement}

The present study was approved by the Bioethics Commission on Animal Experiments of the Ribeirão Preto Medical School, University of São Paulo (protocol number 073/2012), which complies with the ethical principles of animal research.

\section{Sample collection and in vitro maturation}

Ovaries were transported from a local slaughterhouse to the laboratory in $0.9 \%$ saline solution supplemented with $0.05 \mathrm{~g} / \mathrm{L}$ streptomycin at 35 to $37^{\circ} \mathrm{C}$ and washed with $0.9 \%$ saline solution containing penicillin and streptomycin. Viable follicles measuring between 3 and $8 \mathrm{~mm}$ in diameter were aspirated with a 21-gauge needle adapted to a $20 \mathrm{~mL}$ syringe. Subsequently, COCs (Cumulus-oocyte complexes) were recovered from the follicular fluid of ovaries, washed in TALP-HEPES medium and evaluated for morphology under a stereomicroscope. Oocytes with a homogeneous, granulated cytoplasm and sufficient surrounding cumulus cells (with three layers or more), classified as category I or II were selected (Marquant-Le Guienne, 1999). Pools of ten immature COCs from the same cow were randomly assigned to in vitro maturation (IVM) in HEPES-buffered tissue culture medium-199 (TCM-199, Gibco/BRL, Grand Island, NY, USA) supplemented with $10 \%$ fetal calf serum (FCS, Invitrogen Gibco/BRL), $0.2 \mathrm{M}$ sodium pyruvate, $100 \mathrm{IU} / \mathrm{mL}$ penicillin $\mathrm{G}, 100 \mu \mathrm{g} / \mathrm{mL}$ streptomycin, 0.5 $\mu \mathrm{g} / \mathrm{mL}$ follicle stimulating hormone (FSH, FolltropinBioniche, Canada), $5 \mu \mathrm{g} / \mathrm{mL}$ luteinizing hormone ( $\mathrm{LH}$, Lutropin-Bioniche, Canada) and $1 \mu \mathrm{g} / \mathrm{mL} 17 \beta$-estradiol.

Maturation was carried out over a period of 24 $\mathrm{h}$, at $38.5^{\circ} \mathrm{C}$, in an atmosphere with $5 \% \mathrm{CO}_{2}$. Post-IVM, cumulus cells were mechanically removed from three COCs and stored together, in a total of 14 pools of cells. Oocytes were denuded in maturation medium supplemented with 0,2\% hyaluronidase (Sigma-Aldrich, United States), under stereomicroscope. The oocytes presenting extrusion of the first polar body were washed in TCM medium with HEPES and stored in pool of four oocytes in micro tubes containing RNAlater ${ }^{\mathbb{R}} / \mathrm{PBS}(1: 3)$ for further analysis.

\section{Quantification of $m R N A$}

Total RNA was extracted from the samples using the RNeasy ${ }^{\circledR}$ Micro kit (Qiagen, Valencia, California) and all samples were treated with the RNaseFree DNase Set (Qiagen, Valencia, California) to digest all remaining DNA. RNA was reverse transcribed into cDNA with the High-Capacity cDNA Reverse Transcription kit (Applied Biosystems, Foster City, California) according to the manufacturer's protocol. RNA concentration and purity were determined with a NanoDrop ND-2000 spectrophotometer, and samples with a 260/230 ratio higher than 2.0 and 260/280 ratio between 1.8 and 2.1 were selected and used in the subsequent experiment. Due to a low initial amount of cDNA we preamplified the material using the Taqman PreAmp Master Mix kit (Applied Biosystems, Foster City, California). After preliminary testing, the original protocol was modified to our laboratory conditions: $1 \mathrm{X}$ of Taqman PreAmp Master Mix, 0.05X of each assay in a pooled assay mix $(0.2 \mathrm{X})$, and $62.5 \mathrm{ng}$ of cDNA, in a $20-\mu 1$ reaction volume. Preamplification cycles were: $95^{\circ} \mathrm{C}$ for $15 \mathrm{~min}$ and 20 cycles of $95^{\circ} \mathrm{C}$ for $15 \mathrm{sec}$ and $60^{\circ} \mathrm{C}$ for $4 \mathrm{~min}$. The resulting material was diluted $20 \mathrm{X}$ and stored at $20^{\circ} \mathrm{C}$ pending RT-qPCR. According to the manufacturer's instructions, we checked preamplification uniformity using non-limiting cDNA (extracted from ovarian tissue), prepared in the same way as the other samples.

Quantification of gene transcripts was carried out with the reverse transcription real-time polymerase chain reaction (RT-qPCR) using TaqMan $^{\circledR}$ Gene Expression Assays (Applied Biosystems, Foster City, California) available on the ThermoFisher website (http://www.thermofisher.com). The gene expression stability of optimal reference genes in oocytes derived from IVM was not analyzed in Nelore cattle by other authors. Among the reference genes available, eight were chosen for quantification in oocytes and cumulus cells, as follows: $A C T B, G A D P H, B 2 M, H 2 A F Z, G U S B$, HPRT1, PPIA, and TBP (Table 1). Standard curves were generated by RT-qPCR using five 2-fold serial dilutions of preamplified cDNAs as a template to test for assay efficiency (data not shown). RT-qPCR analysis was performed using the Viia-7 system (Applied Biosystems, Foster City, California), in 10- $\mu 1$ reactions containing: 1X TaqMan assay, 1X TaqMan Gene Expression Master Mix (Applied Biosystems, Foster City, California), and $2.5 \mu \mathrm{l}$ of template (preamplified sample diluted 20X). The mean value of the quantification cycle $(\mathrm{Cq})$ was calculated from three technical repetitions per sample. The following cycling conditions were applied for all real-time RT-PCR reactions: initial denaturation at $95^{\circ} \mathrm{C}$ for $15 \mathrm{~min}$ followed by 40 cycles consisting of $95^{\circ} \mathrm{C}$ for $15 \mathrm{sec}$ and $60^{\circ} \mathrm{C}$ for $1 \mathrm{~min}$.

\section{Stability analysis}

Gene expression stability was analyzed using qBasePLUS software v.2.3 (Biogazelle, Zwijnaarde, Belgium) based on the geNorm algorithm (Vandesompele et al., 2002). The algorithm hypothesizes that the expression ratio of two ideal reference genes should be identical in all samples, independently of cell type or experimental design. According to Vandesompele et al., (2002), the software determines the gene-stability measure $(\mathrm{M})$ of a given reference gene using an algorithm based on the mean pairwise variation compared to all other control genes. Larger $M$ values are associated with greater variations in gene expression. geNorm computes the optimal number of reference genes required for accurate normalization by calculating $\mathrm{Vn} / \mathrm{n}+1$ pairwise variation between consecutively ranked normalization factors NFn and $\mathrm{NFn}+1$, where $\mathrm{n}$ and $\mathrm{n}+1$ are the number of genes 
considered, and NFi are the geometric means of the $i$ best candidate reference gene transformed $\mathrm{Cq}$ values. A pairwise variation of 0.15 is suggested as a cut-off value, below which the inclusion of an additional reference gene is not required for reliable normalization (Vandesompele et al., 2002)

\section{Determination of the SOD1 expression profile}

To understand the relevance of reference gene selection for gene expression experiments, a non-reference target gene (SOD1) was used and normalized to different RGs.
$\mathrm{S} O D 1$, also known as superoxide dismutase 1 , is an integrant of the enzymatic antioxidant system related to the balance of free radicals and is expressed in both oocyte and cumulus cells (Cetica et al., 2001). The cDNA for this gene was preamplified and tested with all samples, oocytes and cumulus cells (TaqMan assay Bt03215424_g1 - Applied Biosystems, Foster City, California). Since all real-time RT-PCR assays showed high amplification efficiency, target transcript amounts in each sample were linearized according to Livak and Schmittgen $(2001)$ by $2^{-\Delta \Delta C q}$ (normalized values) to analyze SOD1 gene expression levels.

Table 1. Reference genes to analyze expression stability.

\begin{tabular}{|c|c|c|c|c|}
\hline Gene & Nomenclature & Function & Genebank acess & Taqman assay® \\
\hline$A C T B$ & actin, beta & Cytoskeletal structural protein & NM_173979.3 & Bt03279174_g1 \\
\hline$B 2 M$ & beta-2-microglobulin & $\begin{array}{l}\text { Beta-chain of major } \\
\text { histocompatibility complex } \\
\text { class I molecules }\end{array}$ & NM_173893.3 & $\mathrm{Bt} 03251628 \_\mathrm{ml}$ \\
\hline GAPDH & $\begin{array}{l}\text { glyceraldehyde-3-phosphate } \\
\text { dehydrogenase }\end{array}$ & $\begin{array}{l}\text { Oxidoreductase in glycolysis } \\
\text { and gluconeogenesis }\end{array}$ & NM_001034034.2 & Bt03210913_g1 \\
\hline$G U S B$ & glucuronidase, beta & $\begin{array}{l}\text { Carbohydrate metabolic } \\
\text { process }\end{array}$ & NM_001083436.1 & Bt03256165_ml \\
\hline$H 2 A F Z$ & $\mathrm{H} 2 \mathrm{~A}$ histone family, member $\mathrm{Z}$ & $\begin{array}{l}\text { RNA polymerase II core } \\
\text { promoter sequence-specific } \\
\text { DNA binding }\end{array}$ & NM_174809.2 & Bt03216348_g1 \\
\hline HPRT1 & $\begin{array}{l}\text { hypoxanthine } \\
\text { phosphoribosyltransferase } 1\end{array}$ & $\begin{array}{l}\text { Purine synthesis in salvage } \\
\text { pathway }\end{array}$ & NM_001034035.2 & Bt032225311_g1 \\
\hline PPIA & $\begin{array}{l}\text { peptidylprolyl isomerase A } \\
\text { (cyclophilin A) }\end{array}$ & $\begin{array}{l}\text { Peptidyl-prolyl cis-trans } \\
\text { isomerase activity }\end{array}$ & NM_178320.2 & Bt03224615_g1 \\
\hline$T B P$ & TATA box binding protein & $\begin{array}{l}\text { General RNA polymerase II } \\
\text { in transcription factor }\end{array}$ & NM_001075742.1 & Bt03241946_m1 \\
\hline
\end{tabular}

\section{Results}

Expression profiles of candidate RGs and geNorm analysis of stability

In order to define the best RGs for bovine in vitro matured oocytes and cumulus cells, eight genes were selected for qPCR analysis according to their frequency in the previous literature: $A C T B, G A D P H$, B2M, H2AFZ, GUSB, HPRT1, PPIA, and TBP. The expression profile of candidate RGs, represented as mean $\mathrm{Cq}$ values, were used to determine the most adequate gene for comparative quantification. The amplification data showed a range of $\mathrm{Cq}$ values from 15 to 24 for oocytes and from 9 to 23 for cumulus cells (Figure 1).

The geNorm algorithm revealed gene expression stability among analyzed RGs in oocytes and cumulus cells (Figure 2). An optimal geNorm experiment contains at least 10 representative samples and eight candidate reference targets (Vandesompele et al., 2002). We analyzed eight reference genes in 14 samples of oocytes and cumulus cells. One sample of oocytes contained missing data and was excluded from the analysis. The $H 2 A F Z$ showed no amplification for oocytes and was excluded from the software analysis.

When all oocytes samples were examined together, the average expression stability value (M) was highest for PPIA and lowest and more stable for HPRT1 and $B 2 M$ (Figure 2A). The optimal number of reference targets in this experimental situation is two genes to normalize $\mathrm{qPCR}$ results (geNorm $\mathrm{V}<0.15$ when comparing a normalization factor based on the $2^{\text {nd }}$ or $3^{\text {rd }}$ most stable targets) (Figure 2B). Thus, the optimal normalization factor for oocytes can be calculated as the geometric mean of reference targets $B 2 M$ and HPRT1. $G A P D H$ and $A C T B$ genes, commonly used as RGs, showed less variability between samples when compared to $T B P$ and PPIA, and the most unstable reference gene for expression analysis being the PPIA for IVM oocytes.

The analysis of 14 cumulus samples revealed higher values of $\mathrm{M}$ for $G A P D H$ than the other reference genes, which includes the GAPDH as the more unstable gene for IVM cumulus cells gene expression studies (Figure 2C). On the other hand, the genes HPRT1, $P P I A, B 2 M$, and TBP seem to be more stable for cumulus cell gene expression. The optimal number of reference targets in this experimental situation is 4 (geNorm $\mathrm{V}<0.15$ when comparing a normalization factor based on the $4^{\text {th }}$ or $5^{\text {th }}$ most stable targets). This way, the optimal normalization factor can be calculated as the geometric mean of reference targets HPRT1, PPIA, B2M, and TBP (Figure 2D).

$R G$ validation by quantification of the SOD1 expression profile with different normalization factors

To validate whether the most stable genes selected by the geNorm program were the most suitable to quantify for normalization, different RGs were used 
for normalization of SOD1 expression. As observed in Table 2, unstable RGs lead to alterations in relative gene expression values of SOD1 in both oocytes and cumulus cells, varying between under- and/or over-expression results, while the selected RGs showed good stability and lower variation.
A

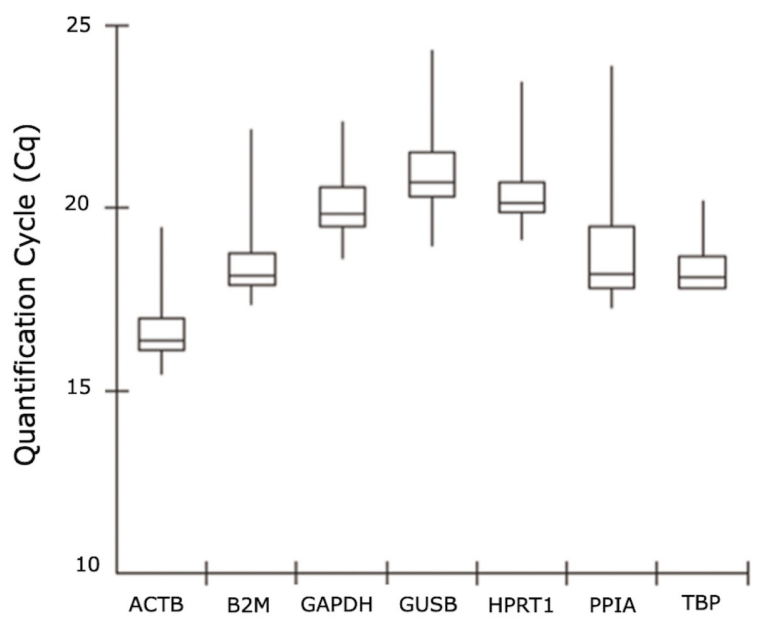

B

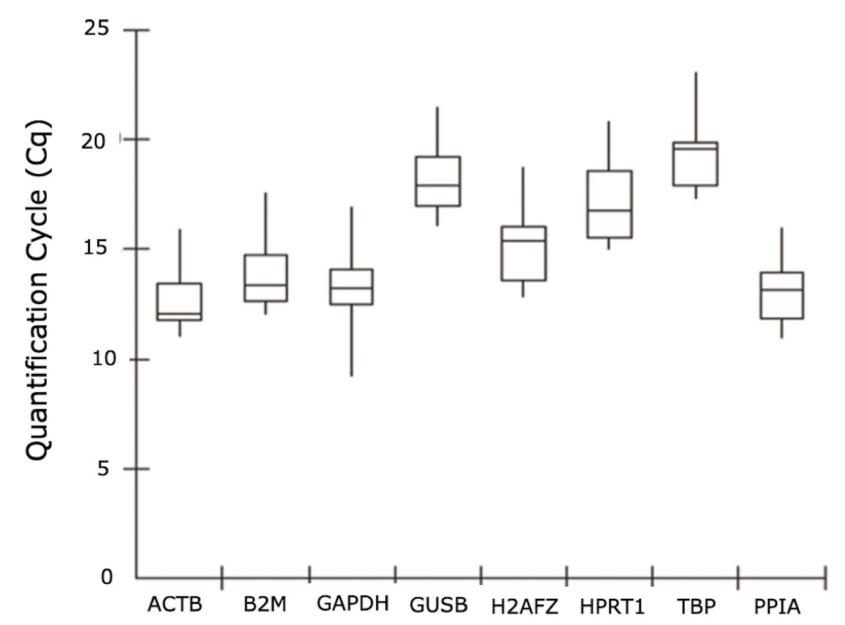

Figure 1. Quantification cycle $(\mathrm{Cq})$ values of candidate RGs across the experimental samples (A) oocyte and (B) cumulus cells. A box-plot graph of $\mathrm{Cq}$ values shows the median values as lines across the box. Upper and lower boxes indicate the $75^{\text {th }}$ percentile to the $25^{\text {th }}$ percentile. Whiskers represent the maximum and minimum values.

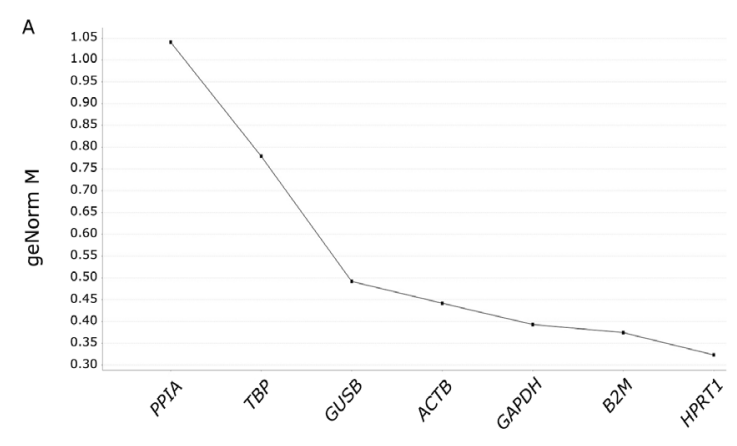

B

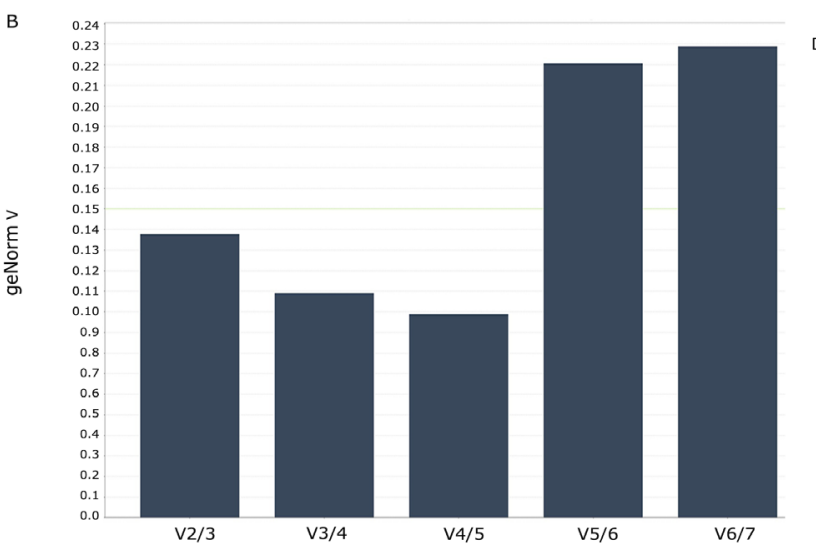

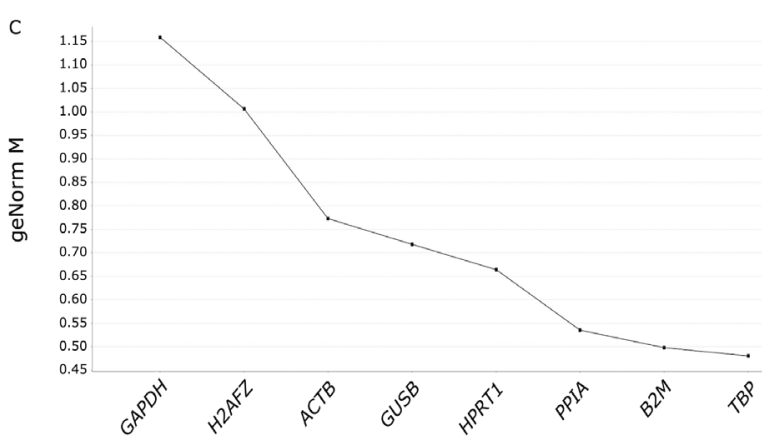

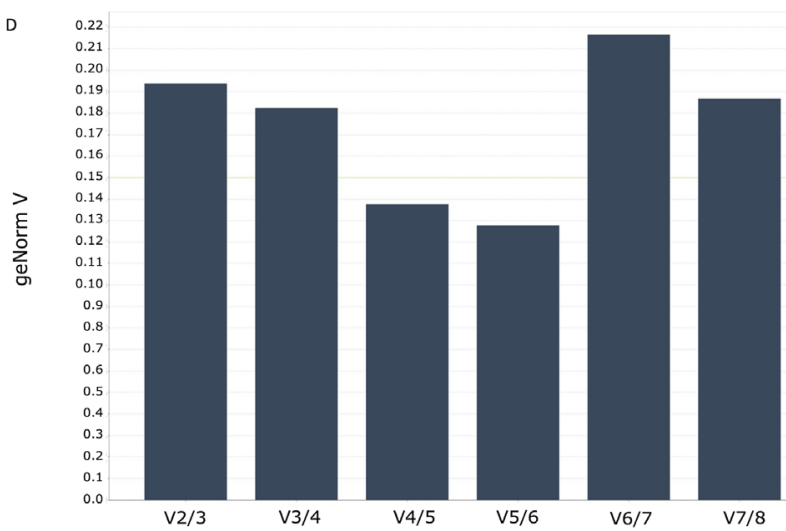

Figure 2. Average expression stability values (geNorm M) of evaluated genes in oocyte (A) and cumulus cells (C) from Nelore cattle, plotted from least stable (left) to most stable gene (right). Graphics B and D shows the gene expression pairwise variation (V) of the candidate RGs calculated by geNorm. Values smaller than 0.15 are considered acceptable as the optimum number of RGs [13]. 
Caetano et al. Reference genes for oocytes and cumulus cells.

Table 2. Relative quantification of SOD1 gene using the different RGs or a combination according geNorm analysis.

\begin{tabular}{|c|c|c|c|c|c|c|c|c|c|c|}
\hline Group & Sample & АСТВ & B2M & GAPDH & GUSB & H2AFZ & HPRT1 & PPIA & TBP & $\begin{array}{l}\text { geNorm } \\
\text { RGs }\end{array}$ \\
\hline \multirow{14}{*}{$\mathrm{CC}$} & $118 \mathrm{~A}$ & 1,02 & 1,23 & 1,58 & 1,35 & 1,64 & 0,91 & 1,87 & 1,19 & 1,26 \\
\hline & $120 \mathrm{~A}$ & 1,32 & 0,98 & 2,88 & 2,47 & 1,86 & 1,01 & 1,18 & 1,33 & 1,12 \\
\hline & $121 \mathrm{~A}$ & 1,13 & 1,13 & 0,85 & 1,39 & 1,77 & 1,14 & 1,46 & 1,24 & 1,23 \\
\hline & $122 \mathrm{~A}$ & 0,93 & 1,57 & 1,66 & 1,98 & 2,64 & 1,55 & 1,61 & 1,92 & 1,66 \\
\hline & $123 \mathrm{~A}$ & 0,58 & 1,38 & 0,15 & 2,27 & 0,85 & 1,75 & 1,84 & 0,92 & 1,42 \\
\hline & $127 \mathrm{~A}$ & 0,80 & 0,92 & 0,92 & 1,41 & 1,47 & 0,77 & 1,82 & 0,89 & 1,03 \\
\hline & $128 \mathrm{~A}$ & 1,08 & 0,81 & 1,33 & 3,43 & 1,38 & 0,94 & 0,84 & 1,17 & 0,93 \\
\hline & $129 \mathrm{~A}$ & 0,86 & 0,52 & 1,22 & 2,55 & 1,07 & 1,17 & 1,44 & 0,57 & 0,84 \\
\hline & $146 \mathrm{~A}$ & 0,66 & 0,47 & 0,08 & 2,48 & 0,20 & 1,48 & 0,55 & 0,48 & 0,66 \\
\hline & $151 \mathrm{~A}$ & 0,49 & 0,31 & 0,73 & 2,25 & 3,15 & 1,74 & 1,31 & 0,65 & 0,82 \\
\hline & $157 \mathrm{~A}$ & 0,25 & 1,05 & 0,76 & 1,40 & 1,69 & 1,94 & 1,41 & 0,96 & 1,29 \\
\hline & $159 \mathrm{~A}$ & 0,53 & 0,94 & 1,24 & 1,80 & 2,21 & 2,34 & 1,81 & 0,94 & 1,39 \\
\hline & $161 \mathrm{~A}$ & 0,20 & 0,50 & 0,20 & 1,66 & 0,26 & 1,64 & 0,82 & 0,48 & 0,75 \\
\hline & $164 \mathrm{~A}$ & 0,64 & 0,59 & 13,09 & 1,27 & 28,53 & 1,47 & 2,00 & 0,85 & 1,10 \\
\hline \multirow{13}{*}{$\mathrm{O}$} & 121 & 0,60 & 0,51 & 0,50 & 0,54 & - & 0,73 & 0,43 & 0,54 & 0,61 \\
\hline & 122 & 0,76 & 1,01 & 0,95 & 1,49 & - & 1,01 & 0,93 & 1,49 & 1,01 \\
\hline & 123 & 1,52 & 1,28 & 1,08 & 1,67 & - & 1,01 & 0,59 & 1,67 & 1,13 \\
\hline & 125 & 2,17 & 2,25 & 1,95 & 1,63 & - & 2,09 & 0,91 & 1,63 & 2,17 \\
\hline & 129 & 1,08 & 1,51 & 1,02 & 0,64 & - & 1,29 & 0,95 & 0,64 & 1,40 \\
\hline & 132 & 1,64 & 1,26 & 0,69 & 0,64 & - & 1,02 & 0,44 & 0,64 & 1,13 \\
\hline & 135 & 0,70 & 1,67 & 0,56 & 1,05 & - & 1,04 & 0,31 & 1,05 & 1,32 \\
\hline & 145 & 1,68 & 1,76 & 1,46 & 1,33 & - & 1,58 & 1,03 & 1,33 & 1,67 \\
\hline & 162 & 0,81 & 1,92 & 2,01 & 1,06 & - & 1,88 & 2,11 & 1,06 & 1,90 \\
\hline & 173 & 1,42 & 1,70 & 1,26 & 0,74 & - & 1,46 & 0,94 & 0,74 & 1,58 \\
\hline & 176 & 0,59 & 0,69 & 1,10 & 0,70 & - & 0,83 & 0,72 & 0,70 & 0,82 \\
\hline & 181 & 1,04 & 1,86 & 1,26 & 1,20 & - & 0,84 & 49,90 & 1,20 & 1,65 \\
\hline & 192 & 0,77 & 1,23 & 1,33 & 0,81 & - & 1,14 & 0,89 & 0,81 & 1,19 \\
\hline
\end{tabular}

CC- cumulus cell samples, O- oocyte samples, and geNorm optimum RGs analyzing cumulus cell samples were: HPRT1, PPIA, B2M, and TBP, and oocytes were: HPRT1 and B2M. H2AFZ did not avalaible in oocytes.

\section{Discussion}

In this study the stability of $A C T B, G A D P H$, $B 2 M$, H2AFZ, GUSB, HPRT1, PPIA, and TBP as reference genes was analyzed in order to select the more adequate one to be used in gene expression studies of bovine oocytes and cumulus cells derived from in vitro maturation. We observed that the best RGs for oocytes gene expression studies were the $B 2 M$ and $H P R T 1$ genes. On the other hand, the HPRT1, PPIA, B2M, and $T B P$ seem to be more stables for cumulus cell sample.

The increasing advancement of molecular biological techniques allows the investigation of gene expression patterns at the transcript level (Hamel et al., 2008; Ross et al., 2009; Salhab et al., 2013). RT-qPCR is a frequently used technology for specific gene expression evaluation and comparative analysis of stable RGs determined for each specific cell type increases reliability (Vandesompele et al., 2002; Radonic et al., 2004; Pfaffl et al., 2004; Andersen et al.,
2004). ACTB, GAPDH, H2AFZ, H2A, HPRT1, PPIA, and $R N A 18 S$ are the most common genes used in such studies involving the bovine model (Patel et al., 2007; Biase et al., 2009; Macabelli et al., 2014). In other mammals, especially human, sheep, and mouse, different reference genes are more common, such as $T B P$, GUSB, and B2M (Ragni et al., 2013).

Although many studies have analyzed gene expression in oocytes and cumulus cells, there was no concordance regarding the ideal combination of RGs for these specific samples, and validation for reference genes is not commonly applied for small samples such as oocytes. However, according to the current consensus is necessary to evaluate the expression stability of RGs for a specific experimental condition (Livak and Schmittgen 2001; Radonic et al., 2004; Dheda et al., 2005).

Macabelli et al., (2014) published their data regarding validation of reference genes for in vivo matured oocytes from Holstein cattle (Bos taurus) and 
buffalo (Bubalus bubalis), analyzing the effect of summer on fertility. They studied $A C T B, G A P D H$, GUSB, HIST1H2AG, HPRT1, PPIA, RPL15, SDHA, $T B P$, and $Y W H A Z$ reference genes and concluded that owing to the high variability of reference genes among their bovine experimental groups, data normalized by internal controls could be misunderstood. They suggested that ideal experiment should include comparisons to non-normalized data or data normalized by an external control, in order to better interpret the biological relevance of gene expression analysis (Macabelli et al., 2014).

In another study, regarding gene expression and maternal aging, reference genes (GAPDH, $A C T B$, UBE2D2, EIF2B2, SF3A1, RNF20) of cumulus cells from dominant follicles in cows (an unrelated bovine breed) were analyzed (Khan et al., 2016). They observed that the geometric mean of multiple genes $(U B E 2 D 2, E I F 2 B 2, G A P D H$, and $S F 3 A 1)$ is a more appropriate reference control than the use of a single reference gene to compare relative gene expression among dominant and FSH-stimulated follicles during maternal and/or follicular aging studies. However, Khan and collaborators (2016) showed that RGs for cumulus cells had a higher variability, may be due to a large number of cells and developmental stages of each cell of the specific COCs. In humans, one study showed that the best RGs for human cumulus cells are $U B C$ and $B 2 M$ (Adriaenssens et al., 2010).

Analyzing different RGs for normalization of SOD1 gene expression, unstable RGs lead to altered gene expression values of SOD1 in both oocytes and cumulus cells. We can observe that greater genetic instability leads to greater variation in gene expression, which may overestimate or underestimate the data, introducing erroneous results (Andersen et al., 2004; Radonic et al., 2004; Hruz et al., 2011; Macabelli et al., 2014). So the validation of the greatest RGs for each gene expression studies using $\mathrm{qPCR}$ is mandatory to have more accurate and robust results, with high specificity, eliminating the bias of qPCR studies. Although we analyzed SOD1 gene expression, in this study we did not evaluate any cumulus specific gene to exclude contamination in oocytes samples by eventual remaining cumulus cells. However, the cumulus cell were carefully removed under stereomicroscope, and the oocytes cells which were not totally cleaned were excluded from this study.

Gene expression studies are great tool to understand and estimate cell stage and physiological responses to environmental alterations. The primary step of these studies is to choose an adequate gene to normalize the expression of a target gene, reducing technical and biological variations. In this context, according to the geNorm algorithm, we suggest HPRT1 and $B 2 M$ to be the best RGs for bovine in vitro matured oocytes and HPRT1, PPIA, B2M, and TBP to be the best normalizers for cumulus cells. To the best of our knowledge, this is the first study validating reference genes in in vitro matured oocytes of Nelore cattle, an important species from an economic standpoint and from a biological point of view for animal breeding programs.

\section{Acknowledgments}

The authors are thank the financial support by Sao Paulo Research Foundation (Fundação de Amparo à Pesquisa do Estado de São Paulo - FAPESP) with the grant (Process number: 2012/06068-3) and fellowships (Process numbers: 2012/06006-8 LCCS, 2012/11069-9 CLMF, and 2012/16444-2 CPPM), National Council for Scientific and Technological Development (Conselho Nacional de Desenvolvimento Científico e Tecnológico - CNPq), CAPES (Coordenação de Aperfeiçoamento de Pessoal de Nível Superior) and the National Institute of Science and Technology (Instituto Nacional de Ciência e Tecnologia - INCT).

\section{References}

Adriaenssens T, Wathlet S, Segers I, Verheyen G, De Vos A, Van der Elst J, Coucke W, Devroey P, Smitz J. 2010. Cumulus cell gene expression is associated with oocyte developmental quality and influenced by patient and treatment characteristics. Hum Reprod, 25:1259-1270.

Andersen CL, Jensen JL, Ørntoft TF. 2004. Normalization of real-time quantitative reverse transcription-PCR data: a model-based variance estimation approach to identify genes suited for normalization, applied to bladder and colon cancer data sets. Cancer Res, 64:5245-5250.

Biase FH, Martelli L, Merighe GK, Santos Biase WK, Miranda M, Smith LC, Meirelles FV. 2009. A retrospective model of oocyte competence: global mRNA and housekeeping transcripts are not associated with in vitro developmental outcome. Zygote, 17: 289295.

Bruzzone R, White TW, Paul DL. 1996. Connections with connexins: the molecular basis of direct intercellular signaling. Eur J Biochem, 238:1-27.

Cammack KM. 2009. Reproductive Traits and Their Heritabilities in Beef Cattle. The Professional Animal Scientis, 25:517-528.

Cetica PD, Pintos LN, Dalvit GC, Beconi MT. 2001. Antioxidant enzyme activity and oxidative stress in bovine oocyte in vitro maturation. IUBMB Life, 51:5764.

Dheda K, Huggett JF, Chang JS, Kim LU, Bustin SA, Johnson MA, Rook GA, Zumla A. 2005. The implications of using an inappropriate reference gene for real-time reverse transcription PCR data normalization. Anal Biochem, 344:141-143.

Gilchrist RB, Lane M, Thompson JG. 2008. Oocytesecreted factors: regulators of cumulus cell function and oocyte quality. Hum Reprod Update, 14:159-177.

Gosden RG. 2002. Oogenesis as a foundation for embryogenesis. Mol Cell Endocrinol, 186:149-153.

Hamel M, Dufort I, Robert C, Gravel C, Leveille MC, Leader A, Sirard MA. 2008. Identification of differentially expressed markers in human follicular cells associated with competent oocytes. Hum Reprod, 23:1118-1127. 
Hruz T, Wyss M, Docquier M, Pfaffl MW, Masanetz S, Borghi L, Verbrugghe P, Kalaydjieva L, Bleuler S, Laule $O$, Descombes $\mathbf{P}$, Gruissem W, Zimmermann P. 2011. RefGenes: identification of reliable and condition specific reference genes for RTqPCR data normalization. BMC Genomics, 12:156.

Khan MI, Dias FC, Dufort I, Misra V, Sirard MA, Singh J. 2016. Stable reference genes in granulosa cells of bovine dominant follicles during follicular growth, FSH stimulation and maternal aging, Reprod Fertil Dev, 28:795-805

Livak KJ, Schmittgen TD. 2001. Analysis of relative gene expression data using real-time quantitative PCR and the 2(-Delta Delta C(T)) Method. Methods, 25:402408.

Macabelli CH, Ferreira RM, Gimenes LU, de Carvalho NA, Soares JG, Ayres H, Ferraz ML, Watanabe YF, Watanabe OY, Sangalli JR, Smith LC, Baruselli PS, Meirelles FV, Chiaratti MR. 2014. Reference gene selection for gene expression analysis of oocytes collected from dairy cattle and buffaloes during winter and summer. PLoS One. 9:e93287.

Marquant-Le Guienne B. 1999. Atlas of the bovine oocyte AETE Newsletter, 10:6-8.

Patel OV, Bettegowda A, Ireland JJ, Coussens PM, Lonergan P, Smith GW. 2007. Functional genomics studies of oocyte competence: evidence that reduced transcript abundance for follistatin is associated with poor developmental competence of bovine oocytes. Reproduction, 133:95-106.

Pfaffl MW, Tichopad A, Prgomet C, Neuvians TP. 2004. Determination of stable housekeeping genes, differentially regulated target genes and sample integrity: BestKeeper-Excel-based tool using pair-wise correlations. Biotechnology Letters, 26:509-515.
Radonić A, Thulke S, Mackay IM, Landt O, Siegert W, Nitsche A. 2004. Guideline to reference gene selection for quantitative real-time PCR. Biochem Biophys Res Commun 313:856-862.

Ragni E, Viganò M, Rebulla $P$, Giordano $R$, Lazzari L. 2013. What is beyond a qRT-PCR study on mesenchymal stem cell differentiation properties: how to choose the most reliable housekeeping genes. $J$ Cell Mol Med, 17:168-180.

Ross DG, Bowles J, Hope M, Lehnert S, Koopman P. 2009. Profiles of gonadal gene expression in the developing bovine embryo. Sex Dev, 3:273-283.

Salhab M, Dhorne-Pollet S, Auclair S, Guyader-Joly C, Brisard D, Dalbies-Tran R, Dupont J, Ponsart C, Mermillod P, Uzbekova S. 2013. In vitro maturation of oocytes alters gene expression and signaling pathways in bovine cumulus cells. Mol Reprod Dev, 80:166-182.

Senbon S, Hirao Y, Miyano T. 2003. Interactions between the oocyte and surrounding somatic cells in follicular development: lessons from in vitro culture. $J$ Reprod Dev, 49:259-269.

Sugiura K, Pendola FL, Eppig JJ. 2005. Oocyte control of metabolic cooperativity between oocytes and companion granulosa cells: energy metabolism. Dev Biol, 279:20-30.

Sutton ML, Gilchrist RB, Thompson JG. 2003. Effects of in-vivo and in-vitro environments on the metabolism of the cumulus-oocyte complex and its influence on oocyte developmental capacity. Hum Reprod Update, 9:35-48.

Vandesompele J, De Preter K, Pattyn F, Poppe B, Van Roy N, De Paepe A, Speleman F. 2002. Accurate normalization of real-time quantitative RT-PCR data by geometric averaging of multiple internal control genes. Genome Biol, 3(7):RESEARCH0034 